\title{
Brachial and sacral plexus neurolymphomatosis - unusual regions for disease relapses
}

\author{
Neurolinfomatose nos plexos braquial e sacral - uma apresentação clínica atípica \\ para recidiva
}

Igor G. PADILHA ${ }^{1,2}$, Thais FISCHER ${ }^{3,4}$, Felipe T. PACHECO ${ }^{1,2}$, Antônio José DA ROCHA 1,2

A 49-year-old man who was diagnosed with diffuse large B cell lymphoma was treated with cyclophosphamide, doxorubicin, vincristine, and prednisone, plus the monoclonal antibody rituximab (R-CHOP protocol) and achieved a confirmed complete response. However, six months later, he complained of superior (upper) and inferior (lower) limb paresthesias. An
MRI of the brachial plexus (Figure 1) and sacral plexus (Figure 2) showed diffuse root enlargement that also demonstrated hypermetabolism on PET-CT (Figure 1D and Figure 2D and $2 \mathrm{E})$, characterizing a disease relapse.

Despite the low frequency of occurrence, the clinician should also be aware of neuropathy as a symptom for disease
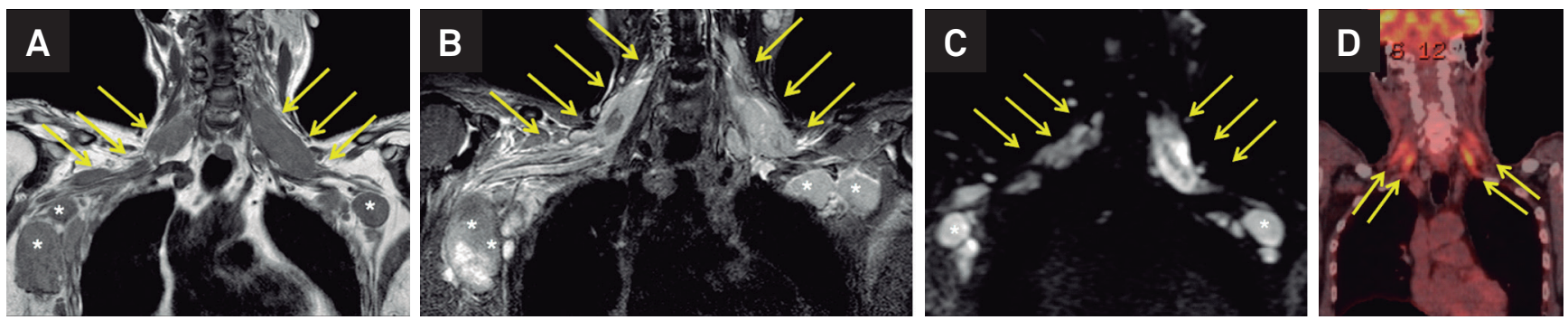

Figure 1. Neuroimaging of the brachial plexus. Brachial plexus MRI coronal T1 WI (A), T2/STIR WI (B) and DWI (C) demonstrating brachial plexus root infiltration with abnormal MR signal intensity (arrows). Note the fusiform aspect in most of the masses, following the larger axis of roots and trunks longitudinally. Enlarged axillar nodes are also depicted (*). PET-CT coronal images (D) reveal noticeable fluorodeoxyglucose hypermetabolism in the brachial plexus.
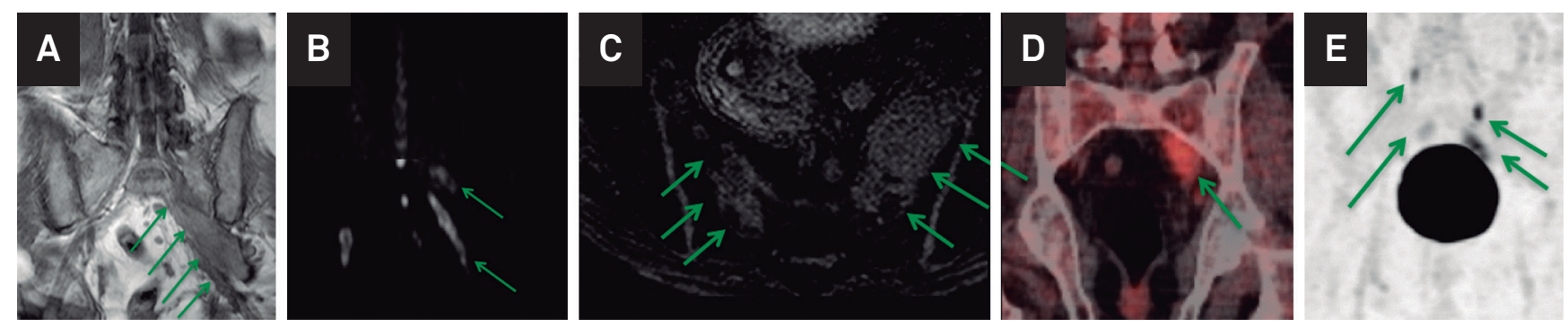

Figure 2. Neuroimaging of the sacral plexus. Sacral plexus MRI coronal T1 WI (A), coronal DWI (B) and axial T2/STIR (C) images also show fusiform masses along the sacral plexus roots and trunks (arrows). PET-CT coronal (D and E) show sacral plexus fluorodeoxyglucose hypermetabolism.

\footnotetext{
${ }^{1}$ Faculdade de Ciências Médicas da Santa Casa de São Paulo, Divisão de Neuroradiologia, São Paulo SP, Brasil;

${ }^{2}$ Diagnosticos da America SA, Departamento de Imagens Médicas, Departamento de Neuroradiologia, São Paulo SP, Brasil;

${ }^{3}$ AC Camargo Cancer Center, Departamento de Oncologia Clínica, São Paulo SP, Brasil;

${ }^{4}$ Faculdade de Ciências Médicas da Santa Casa de São Paulo, São Paulo SP, Brasil;

Igor G. Padilha (iD) https://orcid.org/0000-0002-7639-0397; Thais Fischer iD https://orcid.org/0000-0002-7547-2243; Felipe T. Pacheco iD http://orcid.org/0000-0002-8017-4347; Antônio José da Rocha iD https://orcid.org/0000-0003-2591-9171

Ethical approval: All procedures performed in the studies involving human participants were in accordance with the ethical standards of the institutional and/or national research committee and with the $1964 \mathrm{Helsinki}$ Declaration and its later amendments or comparable ethical standards.

Correspondence: There is no conflict of interest to declare.

Received 02 February 2019; Received in final form 06 March 2019; Accepted 23 March 2019.
} 
recurrence/relapse, allowing for an early diagnosis/treatment. Neurolymphomatosis is a rare lymphoma presentation that occurs when there is direct infiltration of the endoneurium by lymphoma cells ${ }^{1,2}$.

\section{References}

1. Gan HK, Azad A, Cher L, Mitchell PL. Neurolymphomatosis: diagnosis, management, and outcomes in patients treated with rituximab. Neuro Oncol. 2010 Feb;12(2):212-5.

https://doi.org/10.1093/neuonc/nop021
2. Tomita M, Koike H, Kawagashira Y, lijima M, Adachi H, Taguchi J, et al. Clinicopathological features of neuropathy associated with lymphoma. Brain. 2013 Aug;136(8):2563-78. https://doi.org/10.1093/brain/awt193 